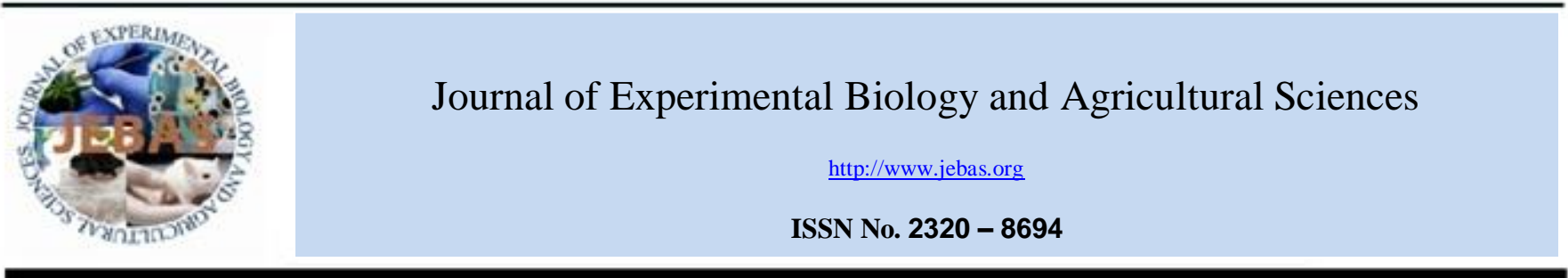

\title{
ALLELOPATHIC PROPENSITY OF THE AQUEOUS LEAF EXTRACT AND LEAF LITTER OF Melia dubia CAV. ON PULSE CROPS
}

\author{
N S Thakur ${ }^{1 *}$, Dinesh Kumar ${ }^{1}$, R P Gunaga ${ }^{1}$, Susheel Singh ${ }^{2}$ \\ ${ }^{1}$ Department of Silviculture and Agroforestry, College of Forestry, \\ ${ }^{2}$ Food Quality Testing Laboratory, N. M. College of Agriculture, Navsari Agricultural University, Navsari, 396450 Gujarat, India
}

Received - July 22, 2017; Revision - September 14, 2017; Accepted - October 10, 2017

Available Online - October 31, 2017

http://dx.doi.org/10.18006/2017.5(5).644.655

KEYWORDS
Allelopathy
Melia dubia
GC-MS
Germination indices
Growth
Yield
Laboratory bioassay
Pot culture

\begin{abstract}
Gas Chromatography Mass-Spectrometry (GC-MS) analysis revealed that leaf litter of Melia dubia contain phenolic acids and its derivatives, unsaturated fatty acid, alkaloids, methyl ketones (volatile allelochemical), aromatic ketone, chromene etc. Further it was reported that the aqueous leaf extracts ( 0 , $25,50,75$ and $100 \%$ concentration) and leaf litter $(0,5,10,15$ and $20 \mathrm{~g} / \mathrm{pot})$ inhibited the germination, growth (shoot length, shoot length and vigour index) and initial biomass (shoot, root and total biomass) of green gram and black chickpea. Percentage of inhibition in germination and initial growth parameters increased with the increasing the concentration of aqueous extract or litter amount of M. dubia. However, pot experiments, carried out till crop maturity, revealed that there was no significant allelopathic effect on growth, biomass and grain yield of the test crops. This indicates that the allelochemicals present in M. dubia leaf litter are volatile in nature and their effect is transient in nature.
\end{abstract}

\footnotetext{
* Corresponding author

E-mail: drnsthakur74@gmail.com (N S Thakur)
}

Peer review under responsibility of Journal of Experimental Biology and Agricultural Sciences.

Production and Hosting by Horizon Publisher India [HPI] (http://www.horizonpublisherindia.in/).

All rights reserved.

All the article published by Journal of Experimental Biology and Agricultural Sciences is licensed under a Creative Commons Attribution-NonCommercial 4.0 International License Based on a work at www.jebas.org.

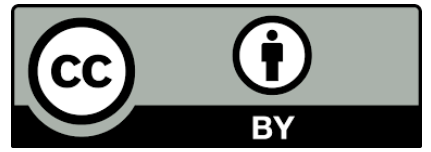




\section{Introduction}

Melia dubia Cav. (Syn. Melia composita Willd.) is being planted in agroforestry system either in block plantation or along the farm boundary. Commonly known as Malabar neem/ Burma neem, is an industrially and economically important fast growing tree species, which can be harvested on a short rotation (Chauhan \& Ritu 2005; Chavan et al., 2015). It is indigenous to the Western Ghats of Southern India and is common in moist deciduous forests of Kerala and outside India, it is found in Sri Lanka, Malaysia, Java, China and Australia (Saravanan et al., 2013). It is valued for its high-quality termite and fungus resistant timber for furniture, agricultural implements and house construction (Suprapti et al., 2004), as alternative pulp wood species, fuel wood and leaf used as a fodder (Parthiban et al., 2009) and has medicinal properties as well (Vijayan et al., 2004). The industrial and ecological importance of $M$. dubia has encouraged the farmers to take large scale plantations with different intercrops (Parthiban et al., 2009; Nuthan et al., 2009).

In some of the woody species, in agroforestry systems, allelopathic effects on under storey crops have been reported (Gupta et al., 2007; Narwal et al., 2011; Gunarathne \& Perera, 2016). Hence to answer such queries of farmers who are interested to integrate this valuable species allelopathic investigations are to be done.

Therefore, keeping in view the importance and increasing popularity of this species, the present investigation was undertaken to investigate the allelochemicals in leaf litter of $M$. dubia to divulge the beneficial or antagonistic effect of aqueous leaf extract and leaf litter on germination, growth, biomass and yield of pulse crops in laboratory bioassay and pot culture.

\section{Materials and methods}

The present investigations were accomplished in the agroforestry laboratory as well as in the green house complex of College of Forestry, ACHF, Navsari Agricultural University, Navsari, Gujarat, India $\left(20.95^{\circ} \mathrm{N}\right.$ latitude, $75.90^{\circ} \mathrm{E}$ longitude with an altitude of $10 \mathrm{~m}$ above MSL) during November 2014 to April 2015.

\subsection{Leaf litter chemical analysis}

The alleged allelopathic compounds in leaf litter samples of $M$. dubia, used in the present study, were detected through Gas Chromatography-Mass Spectrometery (GC-MS) as described by Murugesan et al. (2013).

\subsection{Allelopathic studies}

\subsubsection{Plant material and preparation of aqueous extracts}

The leaf litter (mixture of young and mature leaves showing signs of senescence) of $M$. dubia were collected from 3 year old plantations during October-November 2014. Leaf litter was initially dried at room temperature and later at $65^{\circ} \mathrm{C}$ in hot air oven until constant dry weight was reached (Perez-Corona et al., 2013). The dried leaf litter was stored at room temperature and was used for both peteriplate and pot experiments bioassay. Aqueous extracts were prepared by soaking $200 \mathrm{~g}$ of grounded dried leaf litter in $1 \mathrm{~L}$ distilled water. The solution was stirred and kept at room temperature $\left(20-25^{\circ} \mathrm{C}\right)$ for 24 hours. The filtrate was centrifuged and supernatant was decanted (Prasad et al., 2011). The filtrate was defined as 100 per cent extract and was further diluted with distilled water at $25,50,75,100$ per cent concentrations (Nikneshan et al., 2011) while distilled water was used as control $\mathrm{T}_{1}(0 \%)$ (Lawan et al., 2011).

\subsection{Petridish bioassay experiment}

The seeds (treated with Thirum @ 2g/kg) of green gram [Vigna radiata (L.)] and black chickpea (Cicer arietinum L.) were procured from Pulses and Castor Research Unit, Navsari Agricultural University, Navsari, Gujarat, India. In the laboratory experiment, five treatments of leaf aqueous extracts ( 0 to $100 \%$ concentration) of donor species were used with five replications for each. Each petridish of size $90 \mathrm{~mm}$ diameter was considered as replication. Total 50 seeds of both the test crops were placed on filter paper in sterilized petridishes and $5 \mathrm{ml}$ of aqueous extract was applied on first day and after that, $2 \mathrm{ml}$ was applied at alternate day to keep the filter paper moist till the completion of experiment (Bhat et al., 2011). Seeds were considered germinated upon radicle emergence. Daily germination count was made up to $9^{\text {th }}$ day from day after extract treatment (DAET). Growth and biomass attributes were recorded by randomly selecting 10 seedlings from each replication on $11^{\text {th }}$ DAET. Germination percentage and Germination Rate Index (GRI) were calculated following standard procedure (Anonymous 1983; Anonymous 1985). The shoot, root length and biomass were estimated randomly selecting ten seedlings from each replication on the $11^{\text {th }}$ DAET. Root and shoot portion was dried separately in hot air oven at $60^{\circ} \mathrm{C}$ for $48 \mathrm{~h}$ and then samples were weighed using sensitive balance to estimate biomass.

\subsection{Pot experiment}

Pot experiments were conducted to investigate the effect of leaf litter of M. dubia on germination indices, initial growth and biomass of both the test crops. Leaf litter (course grounded mixture of young and mature leaves showing signs of senescence) 
was used in five concentrations viz., $\mathrm{T}_{1}$ (Control), $\mathrm{T}_{2}(5 \mathrm{~g}), \mathrm{T}_{3}(10$ $\mathrm{g}), \mathrm{T}_{4}(15 \mathrm{~g})$ and $\mathrm{T}_{5}(20 \mathrm{~g})$, these concentration were mixed in the upper soil layer of the pots of concern treatment (Thakur 2014). Soil without leaf litter was used as a control treatment. Each treatment was replicated five times. The litter treatments imposed were according to annual average litter fall (Li et al., 2013), where leaf litter fall of three months data was recorded by placing the 1 $\mathrm{m}^{2}$ traps under 3 years old plantation of $M$. dubia and average leaf litter fall of three months $\left(216.45 \mathrm{~g} / \mathrm{m}^{2}\right)$ was considered and extrapolated for pot with top area of $0.026 \mathrm{~m}^{2}$ i.e. $5.63 \mathrm{~g} / \mathrm{pot}$. Hence, the leaf litter treatments were fixed within the range of average litter fall. Total 50 seeds of each crop were sown in the plastic pots [18 cm diameter x $16 \mathrm{~cm}$ height $(4070 \mathrm{cc})]$ containing approximately $2.5 \mathrm{~kg}$ soil having $\mathrm{N}, \mathrm{P}$ and $\mathrm{K}$ content of 84.82 , 17.85 and $80.35 \mathrm{ppm}$, respectively. Pots were irrigated with tap water $(\mathrm{pH} 7.71$ and electrical conductivity $1.752 \mathrm{dS} / \mathrm{m})$ and seeds were sown after 24 hours. Daily germination count was made up to the last seed to germinate i.e., 8 days. Shoot and root length, and biomass were recorded on the $11^{\text {th }}$ day randomly selecting 10 seedlings from each replication. Shoot and root samples were dried in hot air oven at $60^{\circ} \mathrm{C}$ for $48 \mathrm{~h}$ and then dry biomass was recorded. Germination percentage and Germination Rate Index (GRI) were calculated as per standard procedure followed in the laboratory bioassay.

\subsection{Pot experiments (up to crop maturity)}

In order to evaluate the allelopathic effect of leaf litter till crop maturity a separate experiment was laid out by following same procedure as adopted in pot experiment to study the germination, initial growth and biomass. Each litter treatment was replicated five times (three plants per replication). However, in each pot, only five seeds were sown and one seedling was retained after two weeks of sowing for further observations. The pots were kept in green house with 50 per cent relative shading. Growth parameters such as plant height, root length, no. of leaves, no. of branches, no. of flower, no. of pods per plant and average leaf area per plant was recorded. Furthermore, fresh and dry biomass of plant and grain yield was also recorded at crop maturity, when 80 percent of pods matured ( 3 months after sowing). Pods were separated from the plants and threshed to record the grains.

\subsection{Statistical analysis}

The experimental data of all the parameters studied in different experiments were subjected to the statistical analysis following completely randomized design (CRD) and F-test was done and ANOVA was constructed following Sheron et al. (1998). Treatment means were compared at $\mathrm{P}<0.05$. Further, Duncan's multiple range test (MRT) was used to compare the sets of means of each treatment.

\section{Results and discussion}

\subsection{Leaf litter Phytochemicals}

Gas Chromatography Mass-Spectrometry (GC-MS) screening of M. dubia leaf litter revealed the presence of 18 different types of phytochemicals (Table 1). Among the detected compounds most

Table 1 Chemical compounds, their retention times and area under curve detected in (GC-MS) analysis of M. dubia leaves

\begin{tabular}{|c|c|c|c|}
\hline Sr. No. & Compound name & $\begin{array}{l}\text { Retention } \\
\text { time }\end{array}$ & $\begin{array}{c}\text { Area under } \\
\text { Curve }\end{array}$ \\
\hline 1 & Ethanone 1 (2-aminophenyl), Acetophenone & 5.47 & 131541 \\
\hline 2 & 2 (3-hydroxy-4-methoxyphenyl) 3,5,7 Trimethoxy 4-H-chroman-4-one & 6.79 & 114900 \\
\hline 3 & Papaveroline 6-O-methyl Or 1,2-Benzenediol,4-[(7-hydroxy-6-methoxy-1- isoquinolinyl) methyl] & 9.66 & 408430 \\
\hline 4 & 5-methyl (5-8 dihydro 1-4 Naphthoquinone) or 1,4-aphthalenedione, 5,8-dihydro-5-methyl- & 9.70 & 203565 \\
\hline 5 & 2-propanone, 1-1-diethoxy- or 1,1-diethoxypropan-2-one & 9.77 & 95117 \\
\hline 6 & 2,3,4,5-tetrahydro-1-benzoxepine & 10.57 & 415469 \\
\hline 7 & 1,5 Anhydro-3-6 di-O-acetyl (2,4 di-O-methyl D-glucitol or D-Glucitol, 1,5-anhydro-2,4-di-O-methyl-, diacetate & 11.30 & 696171 \\
\hline 8 & 4-Piperidinol, 1-(2-phenoxyethyl)-4-phenyl- & 12.99 & 55688 \\
\hline 9 & 2,4-Dimethyl-5,6-dithia-2,7-nonadienal, 5-oxide & 14.79 & 348465 \\
\hline 10 & 2-Methyl-3,5-dodecadiyne & 15.14 & 608896 \\
\hline 11 & 1,4 dithiepan-2-one-3-phenyl & 15.39 & 417663 \\
\hline 12 & 1,3-Dioxolane-4-methanol, 2-pentadecyl-, acetate, trans- & 15.56 & 23571 \\
\hline 13 & 2, methyl, 2 phenyl-5 (1-4, dihydropyridine- 4-yidene)-1,3-dioxan-4-6 dione & 15.64 & 52239 \\
\hline 14 & Methyl 4-6 tetradecadiynoate & 16.24 & 115370 \\
\hline 15 & 1H-Purine-2,6-dione, 8-(1,2-dibromo-2-phenylethyl)-3,7-dihydro-1,3,7-trimethyl & 16.95 & 347653 \\
\hline 16 & 3,9 Epoxypregnane-11,14,18 triol-20-one 16 cyano-3methoxy, 11 acetate & 20.74 & 280670 \\
\hline 17 & Eicosapentaenoic Acid or Icosapent & 21.83 & 98308 \\
\hline 18 & Oxazole, 5-ethyl-2-methyl-4-benzoyl- & 26.87 & 352502 \\
\hline
\end{tabular}

Journal of Experimental Biology and Agriculture Science http://www.jebas.org 
common are phenolic acids and their derivatives, omega-3 fatty acid, alkaloids, methyl ketones (volatile allelochemical), unsaturated fatty acids, aromatic ketone and chromene. Chromatograms showing the relative abundance, retention time and area under curve of chemical compounds detected and are presented in figure 1 . The phytochemicals detected in this study through GC-MS have also been reported by Valentina et al. (2013) and Murugesan et al. (2013) in M. dubia extract. Further, the phytochemicals like 3, 4-Dihydroxyacetophenone, 4hydroxybenzoic acid, Piperidinol, Tetradecanoic acid, 2,4Dimethyl-5,6-dithia-2,7-nonadienal, 5-oxide, Icosapentaenoic acid, Naphthoquinone, Purine, D-Glucitol etc., detected in leaf

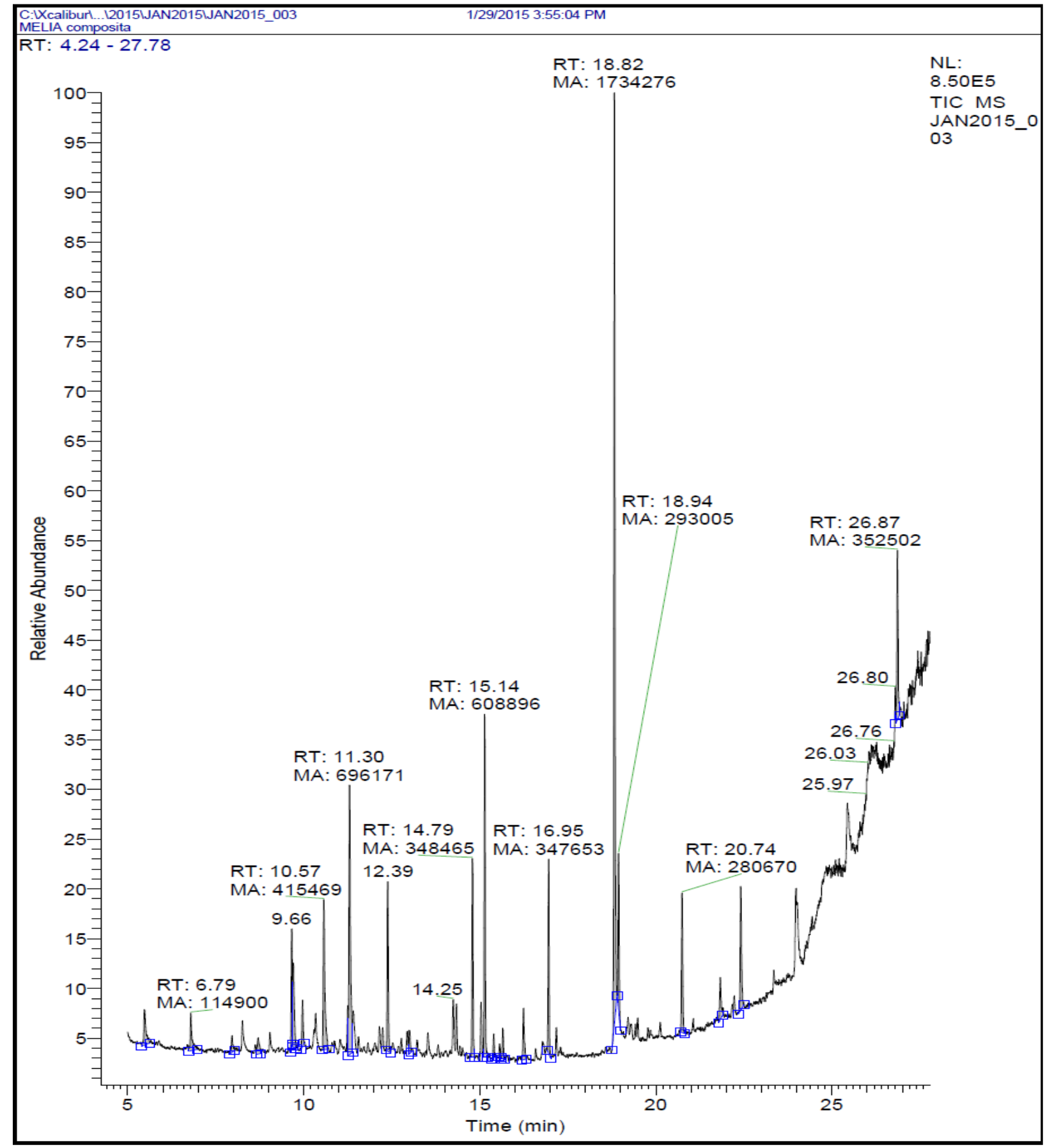

Figure 1 GC-MS chromatogram showing retention time and peaks of different chemical compounds in Melia dubia leaf litter

Journal of Experimental Biology and Agriculture Science http://www.jebas.org 
litter of M. dubia in this study, have been reported in other woody and non woody species and are alleged for their inhibitory allelopathic effect (extract or leaf litter) on germination and growth of various test crops (Suzuki et al., 1996; Duke et al., 2000; Kim \& Kil 2001; Rezaeinodehi et al., 2006; Peneva 2007; Hongying \& Hong 2008; Kato-Naguchi 2008; Koder 2011; Ruan et al., 2011; Jones et al., 2012; Aslani et al., 2014). However, this study has first report of allelopathic nature of leaf litter of M. dubia.

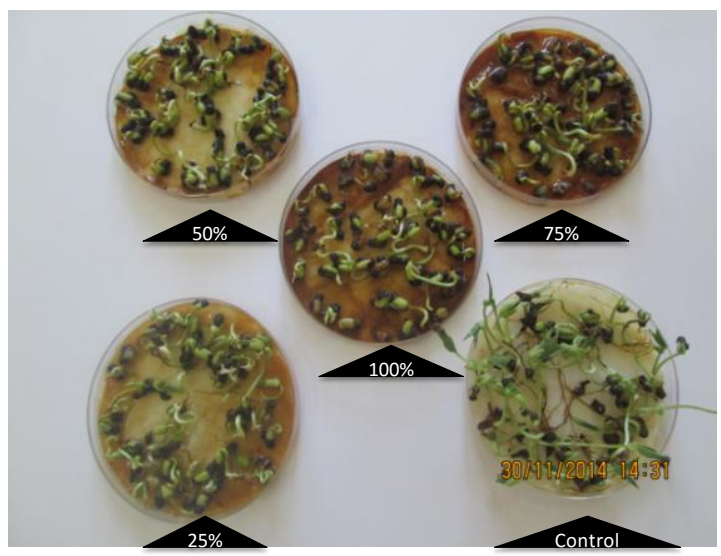

A

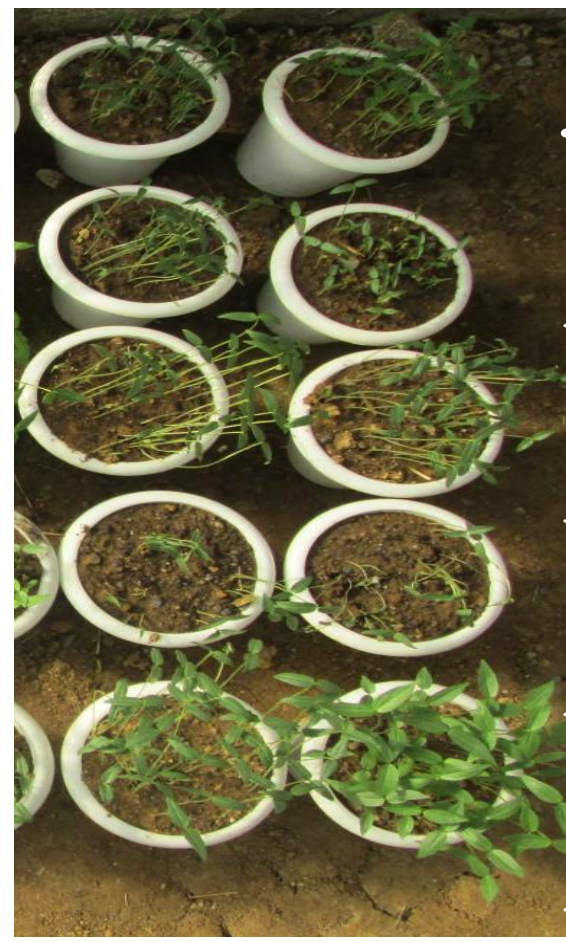

$\mathrm{C}$

$10 \mathrm{~g}$

$15 \mathrm{~g}$

$5 \mathbf{g}$

$20 \mathrm{~g}$

$\mathbf{O} \mathbf{g}$

\subsection{Laboratory and pot culture bioassays: Germination and} its attributes

Laboratory and pot culture bioassays revealed that, aqueous leaf extract and leaf litter of $M$. dubia significantly $(\mathrm{P}<0.05)$ inhibited the germination $(\%)$ and germination rate index (GRI) of green gram and black chickpea (Table 2) relative to control (distilled water or no litter). The inhibitory effect gradually increased with incremental extract concentrations or leaf litter amount, over the control (Figure 2 A to D).

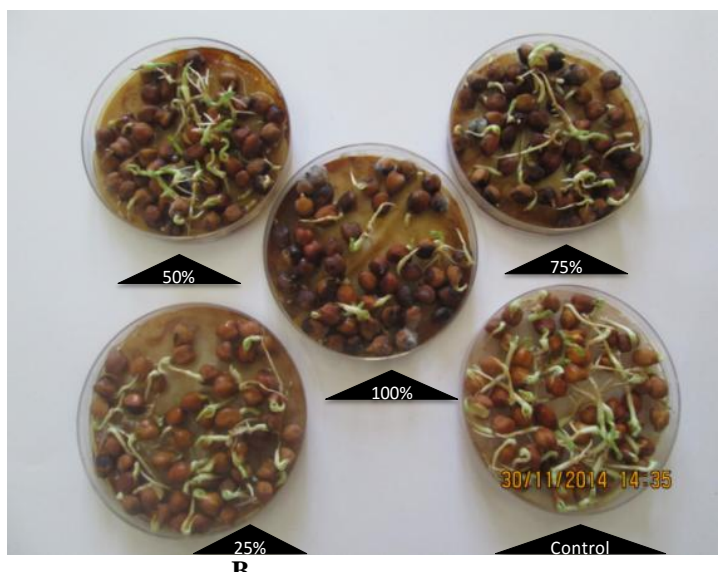

B

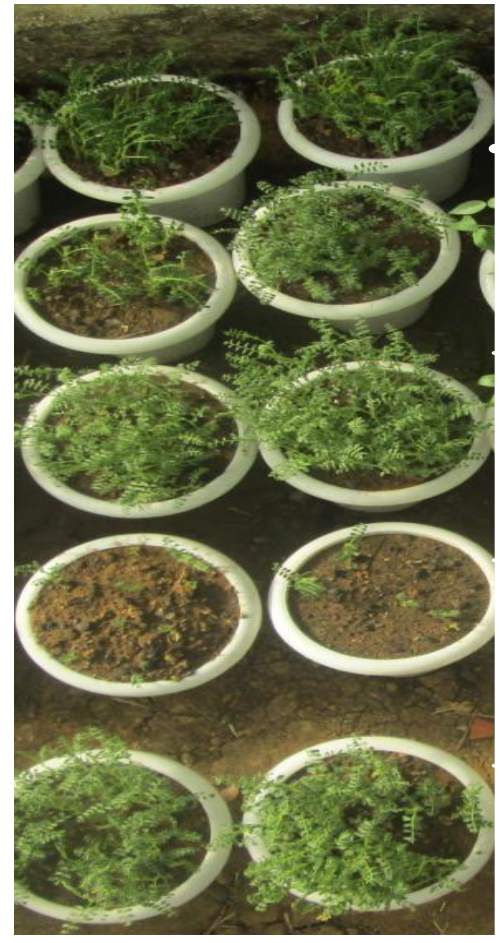

$10 \mathrm{~g}$

Figure 2 Showing the allelopathic influence of aqueous leaf extracts [0, (distilled water), 25, 50, 75 and 100\%] and leaf litter [0 (no leaf litter), 5, 10,15 and $20 \mathrm{~g} / \mathrm{pot}]$ of $M$. dubia on germination and initial growth of green gram and black chickpea in laboratory ( $\mathrm{a}$ and $\mathrm{b}$ ) and pot culture bioassays ( $\mathrm{c}$ and d), respectively. 
The magnitude of per cent inhibition, over control, in all the germination parameters of green gram and black chickpea (Figure 3 to 6) increased with increase in extract concentration and leaf litter quantities with greatest at maximum concentration (100\%) or litter amount (20 g/pot). The per cent reduction on germinations attributes was higher in laboratory bioassays as compared to pot culture.

\subsection{Initial growth and biomass}

The leaf aqueous extract under laboratory and leaf litter in pot culture, exhibited significant $(\mathrm{P}<0.05)$ inhibitory effect on growth parameters viz., shoot and root length of germinated seedling of green gram and black chickpea (Table 2 and 3). The data indicates that, growth parameters had gradual inhibitory effect as the extract concentration or litter quantity increased when compared with the control treatment. The magnitude of per cent inhibition in growth parameters of green gram (Figure 3 \& 5) and black chickpea (Figure 4 \& 6) over control, against aqueous extract and leaf litter, gradually increased with increase in extract concentration or litter amount with maximum at $100 \%$ extract concentration or maximum litter application i.e. $20 \mathrm{~g}$ litter/pot. The per cent reduction was more marked in root growth as compared to shoot except in black chickpea, where shoot length experienced little higher percent reduction, in laboratory bioassay. The reduction percentage was more in laboratory bioassay as compared to pot experiments.

The leaf extracts as well as leaf litter exhibited significant inhibitory effect on shoot, root and total dry biomass of germinated seedlings (Table 2 and 3). The magnitude of diminution progressed gradually with increase in leachate concentration or litter application over the control with maximum at $100 \%$ extract concentration and $20 \mathrm{~g}$ leaf litter/pot.

Intensity of per cent inhibition, over control, in growth traits of green gram and black chickpea (Figure 3 to 6), increased with increase in extract concentration or leaf litter quantities of M. dubia. All the biomass attributes experienced greater magnitude of reduction due to aqueous extracts compared to litter application in pots, over control treatments.

The magnitude of inhibition on germination indices, initial growth and biomass of seedlings increased with incremental aqueous extract concentration and leaf litter quantity. This showed concentration dependent effect of
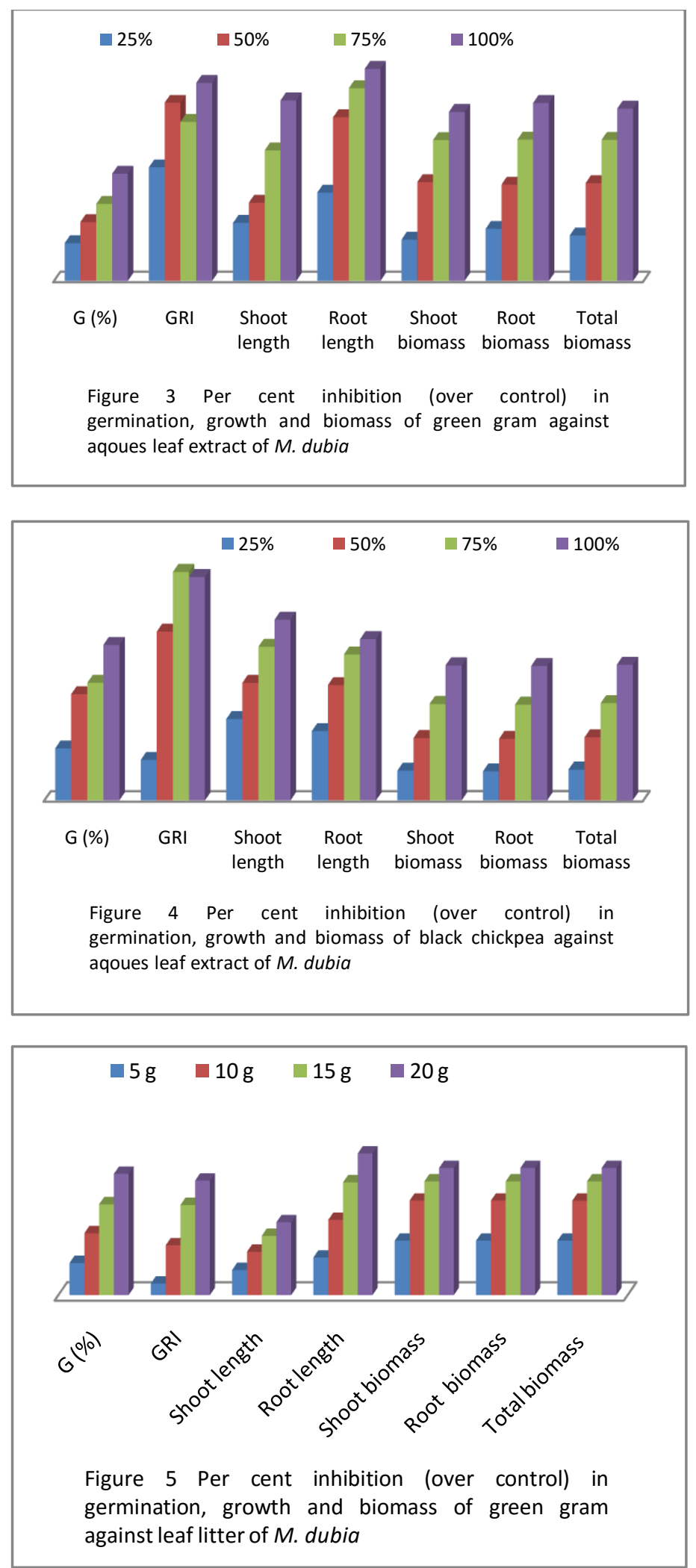


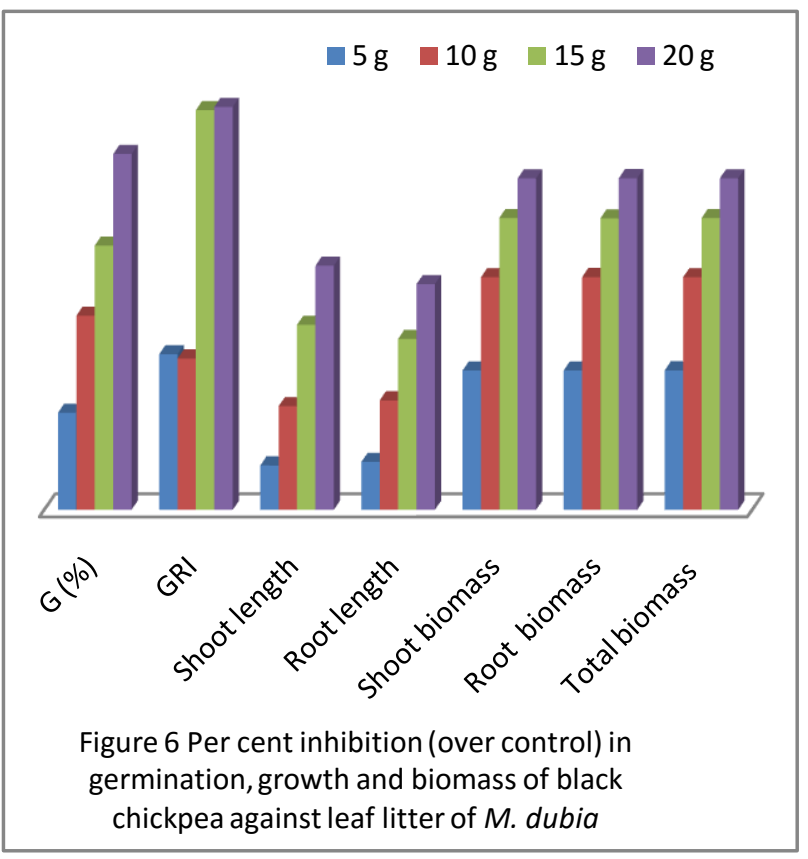

aqueous extract and leaf litter. The findings are in congruence with earlier laboratory bioassays of $M$. azedarach on pulse crops (Phuwiwat et al., 2012; Akacha et al., 2013). This may be attributed to water soluble nature allelochemicals (Table 4) in leaf litter (Rezaeinodehi et al., 2006).Petridish bioassay and pot culture experiments revealed that per cent depression effect was more pronounced on root growth in laboratory bioassay as well as in pot experiments. Similar organ specific effects of M. azedarach leaf aqueous extracts have been reported earlier (Lungu et al., 2011; Phuwiwat et al., 2012; Akacha et al., 2013). This may be attributed to the fact that roots first come in contact with allelochemicals and are the first to absorb them from the environment in which they are growing and cell death and tissue browning frequently occur in the root apical zone, an area with active cell division (Rezaeinodehi et al., 2006; Ding et al., 2007).

Similar to present findings, it has been reported that young seedlings are more sensitive to allelopathicals compared to adult plants or other plant organs, especially the roots (Wu et al., 2007; Zhang et al., 2010).

Table 2 Effect of aqueous leaf extract of M. dubia on germination traits, initial growth and biomass green gram and black chickpea

\begin{tabular}{|c|c|c|c|c|c|c|c|}
\hline \multirow{2}{*}{$\begin{array}{l}\text { Extract concen- } \\
\text { tration }(\%)\end{array}$} & \multicolumn{2}{|c|}{ Germination traits } & \multicolumn{2}{|c|}{ Growth $(\mathrm{cm})$} & \multicolumn{3}{|c|}{ Biomass (DM mg/plant) } \\
\hline & $\mathbf{G}(\%)$ & GRI & $\begin{array}{l}\text { Shoot } \\
\text { length }\end{array}$ & Root length & Shoot & Root & Total \\
\hline \multicolumn{8}{|c|}{ Green gram } \\
\hline Control $(0 \%)$ & $97.60(77.17)^{\mathrm{a}}$ & $91.36^{\mathrm{a}}$ & $7.31^{\mathrm{a}}$ & $2.90^{\mathrm{a}}$ & $13.82^{\mathrm{a}}$ & $8.83^{\mathrm{a}}$ & $22.65^{\mathrm{a}}$ \\
\hline $25 \%$ & $87.60(69.29)^{\mathrm{b}}$ & $63.16^{\mathrm{b}}$ & $6.15^{\mathrm{b}}$ & $2.89^{\mathrm{a}}$ & $12.27^{\mathrm{b}}$ & $7.58^{\mathrm{b}}$ & $19.85^{\mathrm{b}}$ \\
\hline $50 \%$ & $82.00(65.04)^{\mathrm{c}}$ & $51.86^{\mathrm{c}}$ & $5.75^{\mathrm{c}}$ & $2.11^{\mathrm{ab}}$ & $10.11^{\mathrm{c}}$ & $6.52^{\mathrm{c}}$ & $16.63^{\mathrm{c}}$ \\
\hline $75 \%$ & $77.20(60.95)^{\mathrm{c}}$ & $47.14^{\mathrm{c}}$ & $4.71^{\mathrm{d}}$ & $1.81^{\mathrm{b}}$ & $8.53^{\mathrm{d}}$ & $5.44^{\mathrm{d}}$ & $13.97^{\mathrm{d}}$ \\
\hline $100 \%$ & $69.20(55.19)^{\mathrm{d}}$ & $42.19^{\mathrm{c}}$ & $3.72^{\mathrm{e}}$ & $1.61^{\mathrm{b}}$ & $7.47^{\mathrm{e}}$ & $4.56^{\mathrm{e}}$ & $12.04^{\mathrm{e}}$ \\
\hline $\mathrm{CD}(\mathrm{P} \leq 0.05)$ & 2.99 & 2.45 & 0.20 & 0.22 & 0.79 & 0.33 & 1.05 \\
\hline $\operatorname{SEm}( \pm)$ & 1.01 & 0.83 & 0.07 & 0.08 & 0.27 & 0.11 & 0.35 \\
\hline \multicolumn{8}{|c|}{ Black chickpea } \\
\hline Control $(0 \%)$ & $97.20(80.47)^{\mathrm{a}}$ & $37.95^{\mathrm{a}}$ & $3.40^{\mathrm{a}}$ & $4.00^{\mathrm{a}}$ & $23.33^{\mathrm{a}}$ & $21.25^{\mathrm{a}}$ & $44.80^{\mathrm{a}}$ \\
\hline $25 \%$ & $80.80(64.02)^{\mathrm{b}}$ & $30.91^{\mathrm{ab}}$ & $2.50^{\mathrm{b}}$ & $3.10^{\mathrm{b}}$ & $21.07^{\mathrm{b}}$ & $19.25^{\mathrm{b}}$ & $40.32^{\mathrm{b}}$ \\
\hline $50 \%$ & $63.60(52.89)^{\mathrm{c}}$ & $25.01^{\mathrm{bc}}$ & $2.10^{\mathrm{c}}$ & $2.50^{\mathrm{c}}$ & $18.60^{\mathrm{c}}$ & $17.00^{\mathrm{c}}$ & $35.60^{\mathrm{c}}$ \\
\hline $75 \%$ & $60.00(50.82)^{\mathrm{c}}$ & $19.50^{\mathrm{c}}$ & $1.70^{\mathrm{d}}$ & $2.10^{\mathrm{d}}$ & $16.01^{\mathrm{d}}$ & $14.63^{\mathrm{d}}$ & $30.63^{\mathrm{d}}$ \\
\hline $100 \%$ & $48.00(43.83)^{\mathrm{d}}$ & $14.96^{\mathrm{c}}$ & $1.40^{\mathrm{e}}$ & $1.90^{\mathrm{e}}$ & $13.08^{\mathrm{e}}$ & $11.95^{\mathrm{e}}$ & $25.03^{\mathrm{e}}$ \\
\hline $\mathrm{CD}(\mathrm{P} \leq 0.05)$ & 4.10 & 1.49 & 0.12 & 0.12 & 1.29 & 1.05 & 2.48 \\
\hline $\operatorname{SEm}( \pm)$ & 1.38 & 0.50 & 0.04 & 0.04 & 0.44 & 0.35 & 0.84 \\
\hline
\end{tabular}

*Figures in parenthesis are the transformed values; G=Germination; GRI=Germination Rate Index; MDG=Mean Daily Germination; DM=Dry Matter; $\mathrm{CD}=$ Critical difference; $\mathrm{SEM}=$ Standard error of mean, Letter different in same vertical column are significantly different according to Duncan's multiple range test $(\mathrm{P} \leq 0.05)$.

Journal of Experimental Biology and Agriculture Science http://www.jebas.org 
Table 3 Effect of leaf litter of M. dubia on germination traits, initial growth and biomass of green gram and black chickpea in pot culture

\begin{tabular}{|c|c|c|c|c|c|c|c|}
\hline \multirow{2}{*}{$\begin{array}{l}\text { Leaf litter } \\
\text { (g/pot) }\end{array}$} & \multicolumn{2}{|c|}{ Germination traits } & \multicolumn{2}{|c|}{ Growth $(\mathbf{c m})$} & \multicolumn{3}{|c|}{ Biomass (DM mg/plant) } \\
\hline & $\mathbf{G}(\%)$ & GRI & Shoot length & Root length & Shoot & Root & Total \\
\hline \multicolumn{8}{|c|}{ Green Gram } \\
\hline No litter & $94.80(77.07)^{\mathrm{a}}$ & $24.24^{\mathrm{a}}$ & $15.50^{\mathrm{a}}$ & $12.20^{\mathrm{a}}$ & $47.52^{\mathrm{a}}$ & $26.61^{\mathrm{a}}$ & $74.12^{\mathrm{a}}$ \\
\hline $5 \mathrm{~g}$ & $86.20(68.18)^{\mathrm{b}}$ & $23.44^{\mathrm{ab}}$ & $14.40^{\mathrm{b}}$ & $10.90^{\mathrm{b}}$ & $40.19^{b}$ & $22.51^{\mathrm{b}}$ & $62.70^{\mathrm{b}}$ \\
\hline $10 \mathrm{~g}$ & $78.20(62.15)^{\mathrm{c}}$ & $20.82^{\mathrm{b}}$ & $13.60^{\mathrm{c}}$ & $9.60^{\mathrm{c}}$ & $34.80^{\mathrm{c}}$ & $19.49^{c}$ & $54.30^{\mathrm{c}}$ \\
\hline $15 \mathrm{~g}$ & $70.40(57.03)^{\mathrm{d}}$ & $18.05^{\mathrm{c}}$ & $12.90^{\mathrm{d}}$ & $8.30^{\mathrm{d}}$ & $32.20^{\mathrm{cd}}$ & $18.03^{\text {cd }}$ & $50.23^{\text {cd }}$ \\
\hline $20 \mathrm{~g}$ & $62.20(52.05)^{\mathrm{e}}$ & $16.37^{\mathrm{c}}$ & $12.30^{\mathrm{e}}$ & $7.30^{\mathrm{e}}$ & $30.39^{\mathrm{d}}$ & $17.02^{\mathrm{d}}$ & $47.41^{\mathrm{d}}$ \\
\hline $\begin{array}{l}\text { CD (P } \\
\leq 0.05)\end{array}$ & 2.61 & 0.71 & 0.43 & 0.94 & 2.34 & 0.89 & 4.50 \\
\hline $\operatorname{SEm}( \pm)$ & 0.88 & 0.24 & 0.14 & 0.32 & 0.79 & 0.30 & 1.51 \\
\hline \multicolumn{8}{|c|}{ Black chickpea } \\
\hline No litter & $94.40(76.75)^{\mathrm{a}}$ & $12.19^{\mathrm{a}}$ & $17.20^{\mathrm{a}}$ & $18.60^{\mathrm{a}}$ & $59.27^{\mathrm{a}}$ & $32.04^{\mathrm{a}}$ & $91.31^{\mathrm{a}}$ \\
\hline $5 \mathrm{~g}$ & $87.20(69.04)^{b}$ & $10.70^{\mathrm{a}}$ & $16.60^{\mathrm{ab}}$ & $17.90^{\mathrm{ab}}$ & $52.78^{\mathrm{b}}$ & $28.53^{b}$ & $81.30^{\mathrm{b}}$ \\
\hline $10 \mathrm{~g}$ & $80.00(63.44)^{\mathrm{c}}$ & $10.74^{\mathrm{a}}$ & $15.80^{\mathrm{bc}}$ & $17.00^{\mathrm{bc}}$ & $48.44^{\mathrm{c}}$ & $26.18^{\mathrm{c}}$ & $74.62^{\mathrm{c}}$ \\
\hline $15 \mathrm{~g}$ & $74.80(59.87)^{\mathrm{d}}$ & $8.36^{\mathrm{b}}$ & $14.70^{\mathrm{c}}$ & $16.10^{\mathrm{c}}$ & $45.68^{\mathrm{d}}$ & $24.70^{\mathrm{d}}$ & $70.38^{\mathrm{d}}$ \\
\hline $20 \mathrm{~g}$ & $68.00(55.53)^{\mathrm{e}}$ & $8.33^{\mathrm{b}}$ & $13.90^{\mathrm{c}}$ & $15.30^{\mathrm{c}}$ & $43.83^{\mathrm{e}}$ & $23.69^{\mathrm{e}}$ & $67.52^{\mathrm{e}}$ \\
\hline $\begin{array}{l}\mathrm{CD}(\mathrm{P} \\
\leq 0.05)\end{array}$ & 3.09 & 0.63 & 0.41 & 0.68 & 0.91 & 0.49 & 1.40 \\
\hline $\operatorname{SEm}( \pm)$ & 1.04 & 0.21 & 0.14 & 0.23 & 0.31 & 0.17 & 0.47 \\
\hline
\end{tabular}

*Figures in parenthesis are the transformed values; G=Germination; GRI=Germination Rate Index; MDG=Mean Daily Germination; DM=Dry Matter; $\mathrm{CD}=$ Critical difference; $\mathrm{SEM}=$ Standard error of mean, Letter different in same vertical column are significantly different according to Duncan's multiple range test $(\mathrm{P} \leq 0.05)$.

This study is the first to report the allelopathic nature of M. dubia leaf extract and leaf litter. Similar compounds have been detected in M. azedarach, member of same family, alleged for allelopathic influence on germination and initial growth and biomass of various crops (Mulatu et al., 2011; Shapla et al., 2011). The aqueous leaf extracts of plant species may hamper physiological processes of germinating seeds and growing seedlings. Such physiological hindrances might have resulted due to allelochemicals of $M$. dubia in present investigations. Phuwiwat et al. (2012) observed that water uptake and $\alpha$-amylase activity of Echinochloa crusgalli was inhibited by aqueous extracts of young leaves $(12.5$ to $100 \mathrm{mg} / \mathrm{mL})$ of $M$. azedarach and water soluble allelochemicals caused inhibition of both water uptake and $\alpha$ amylase activity during germination process as compared to control. Metabolism activation within seed occurs in adequate moisture (Chong et al., 2002), which may be restricted in germinating seeds due to inhibition of specific enzymes. Germination inhibition could be the result of induction of oxidative stress (Javed, 2011).
All these findings may be ascribed to the inhibitory effect of $M$. dubia aqueous extracts on seed germination of green gram and black chickpea in the present study. Earlier studies showed that addition of leachates or incorporation of plant residues into the growth environment of another plant can result in inhibition effect on germination and growth due to depletion of the nitrogen content and impeding of the physiological processes of the seedlings growing in such environment (Al-Khatib et al., 1997). Similar effects might have resulted in reduced germination, growth and biomass of black gram against leaf mulch of M. dubia as compared to control in the present study. Akacha et al. (2013) reported that $M$. azedarach allelelo-chemicals produced an imbalance in the oxidative status of cells and these allelelochemicals made changes in activity of catalase (CAT), ascorbate peroxidase (APX), guaiacol peroxidase (GPX) as well as in the levels of $\mathrm{H}_{2} \mathrm{O}_{2}$ and assimilatory pigments.

Allelochemicals have been alleged to decrease the stomatal conductance due to induced $\mathrm{ABA}$ production, which indirectly impact the photosynthesis, transpiration, respiration rates and 
Table 4 Effect of leaf litter of M. dubia on growth, biomass and grain yield (3 MAS) of green gram and black chickpea in pot culture

\begin{tabular}{|c|c|c|c|c|c|}
\hline Leaf litter (g/pot) & Plant Height (cm) & Collar diameter (mm) & $\begin{array}{l}\text { Root length } \\
\quad(\mathrm{cm})\end{array}$ & $\begin{array}{l}\text { Grain yield } \\
\text { (g/ plant) }\end{array}$ & Biomass (DM g/ plant) \\
\hline & \multicolumn{5}{|c|}{ Green Gram } \\
\hline No litter & 54.43 & 2.62 & 21.40 & 2.20 & 7.69 \\
\hline $5 \mathrm{~g}$ & 48.94 & 2.71 & 20.90 & 2.23 & 7.11 \\
\hline $10 \mathrm{~g}$ & 49.93 & 2.70 & 22.93 & 2.18 & 7.76 \\
\hline $15 \mathrm{~g}$ & 50.94 & 2.38 & 21.91 & 2.50 & 7.70 \\
\hline $20 \mathrm{~g}$ & 49.52 & 2.52 & 20.35 & 2.01 & 6.30 \\
\hline $\mathrm{CD}(\mathrm{P} \leq 0.05)$ & N.S. & N.S. & N.S. & N.S. & N.S. \\
\hline \multirow[t]{2}{*}{ SEm ( $( \pm)$} & 2.50 & 0.19 & 2.64 & 0.20 & 1.08 \\
\hline & \multicolumn{5}{|c|}{ Black chickpea } \\
\hline No litter & 35.25 & 2.83 & 6.78 & $*$ & 4.72 \\
\hline $5 \mathrm{~g}$ & 33.43 & 2.80 & 7.02 & $*$ & 4.33 \\
\hline $10 \mathrm{~g}$ & 34.33 & 3.23 & 7.19 & $*$ & 4.68 \\
\hline $15 \mathrm{~g}$ & 32.01 & 2.78 & 6.03 & $*$ & 4.36 \\
\hline $20 \mathrm{~g}$ & 34.74 & 2.82 & 7.03 & $*$ & 4.61 \\
\hline $\mathrm{CD}(\mathrm{P} \leq 0.05)$ & N.S. & N.S. & N.S. & $*$ & N.S. \\
\hline $\operatorname{SEm}( \pm)$ & 1.98 & 0.29 & 0.42 & $*$ & 0.24 \\
\hline
\end{tabular}

MAS= Months after sowing: DM=Dry Matter; *Grain formation did not occur; $\mathrm{CD}=$ Critical difference; SEM= Standard error of mean

uncoupling oxidative phosphorylation (Yu et al., 2003; Bagavathy \& Xavier, 2007). Multiple physiological effects, such as reduction in plant growth, absorption of water and mineral nutrients, ion uptake, leaf water potential, shoot turgor pressure, physiological drought and osmotic potential have been attributed to reduction in germination, growth and biomass seedlings both in laboratory bioassay and pot experiments (Barkosky \& Einhellig 2003; Rezaeinodehi et al., 2006).

3.4 Allelopathic effect of leaf litter on growth, biomass and grain yield at harvesting

The data on growth, biomass and grain yield (3 months after sowing) attained by green gram and black chickpea (Table 4) expressed that there was no significant effect of leaf litter of $M$. dubia applied @0, 5, 10, 15 and 20 g/pot, on growth, biomass and grain yield both the test crops.

Despite validation of allelochemicals in M. dubia through GC-MS analysis, the leaf mulch treatments did not exhibit inhibitory or stimulatory effect on later stage of growth of green gram and black chickpea in the present study. In contrary to present findings, Shapla et al. (2011) reported that M. azedarach, sister species of M. dubia, mulch application @ $20 \mathrm{gm} /$ pot inhibited the growth (shoot and root length, number of leaves) and biomass (shoot, root and total fresh and dry) of mung bean and soybean. Similar adverse effects of leaf mulch of fruit and timber tree species on other pulse and cereal crops have also been reported (Sale \& Oyun 2013; Thakur, 2014). Studies on pot culture carried out by Divya et al. (2004) and Hossain et al. (2002) are also divergent to the present findings. These studies have reported inhibitory effect of leaf litter application only up to a month or so. However, in this study, results of growth, biomass and yield are reported till maturity of the test crops.

This may be attributed to faster mulch decomposition, leaching out of allelo-chemicals due to frequent irrigation done to maintain the moisture in the pots, ephemeral nature of allelo-chemicals, loss from soil through volatilization, especially phenolics (Ampofo 2009; Narwal et al. 2011). Management practices like frequent watering may have resulted in faster decomposition of leaf mulch of $M$. dubia, hence did not exhibited any significant inhibitory effect on growth, yield and dry matter production of pulse crops in present study. The mulch used in the present study was crushed and reduced in size before application, which might have resulted in quick decomposition, thus, alleviating the allelochemicals. These evidences may be attributed to nonsignificant effect of mulch treatments of M. dubia on growth, biomass and grain yield of test crops in the present study.

Laboratory bioassay and pot culture studies divulged that, the leaf litter of M. dubia contain different types of phytotoxic chemicals, as evident from the GC-MS analysis, with putative inhibitive potential on seed germination, initial growth and biomass of green 
gram and black chickpea. However, pot culture studies, revealed that there was no significant allelopathic effect on later growth, biomass and grain yield of both the test crops. The second investigation brought out that allelochemicals in leaf litter of $M$. dubia are of ephemeral nature and their effect got alleviate over of time.

\section{Conflict of Interest}

Authors would hereby like to declare that there is no conflict of interests that could possibly arise.

\section{References}

Akacha M, Boughanmi NG, Haouala R (2013) Effects of Melia azedarach leaves extracts on radish growth and oxidative status. International Journal of Botany and Research 3: 29-42.

Al-khatib K, Libbey C, Boydston R (1997) Weed suppression with brassica green manure crops in green pea. Weed Science 45 : 439-445.

Ampofo KG (2009) Effect of Tectona grandis leaf extract mulch and woodlot soil on germination and growth of maize. M.Sc. thesis submitted to the Kwame Nkrumah University of Science and Technology Kumasi, Ghana.

Anonymous (1983) Association of official seed analysis (AOSA). Seed vigor testing handbook. Contribution no. 32 to the handbook on seed testing. Association of Official Seed Analysis, Springfield.

Anonymous (1985) International Seed Testing Association (ISTA). International rules for seed testing. Seed Science and Technology 13: 307-513.

Aslani F, Juraimia AS, Ahmad-Hamdania MS, Omarb D, Alam MA, Hashemi FSC, Hakim MD, Uddin MK (2014) Allelopathic effect of methanol extracts from Tinospora tuberculata on selected crops and rice weeds. Acta Agriculturae Scandinavica, Section B-Soil Plant Science 64:165-177.

Bagavathy S, Xavier GSA (2007) Effects of aqueous extract of Eucalyptus globulus on germination and seedling growth of sorghum. Allelopathy Journal 20: 395-402.

Barkosky RR, Einhellig FA (2003) Allelopathic interference of plant-water relationships by parahydroxybenzoic acid. Botanical Bulletin- Academia Sinica 44: 53-58.

Bhat JA, M Kumar, Singh B (2011) Effect of leaf and bark aqueous extract of Anogeissus latifolia on growth performance of Vigna unguiculata. Agricultural Sciences 4: 432-434.
Chauhan SK, Ritu (2005) Towards agroecological health diversifying traditional crop rotation through agroforestry in Punjab India. APA News 21: 3-4.

Chavan SB, Keerthika A, Dhyani SK, Handa AK, Newaj Ram, Rajarajan K (2015). National Agroforestry Policy in India: a low hanging fruit. Current Science 108: 1826-1834

Chong C, Bible BB, Ju HY (2002) Germination and emergence. In: Pessarakli M (Ed.) Handbook of Plant and Crop Physiology Second edition, pp. 57-115. Marcel Deckker Inc New York.

Ding J, Sun Y, Xiao CL, Shi K, Zhou YH, Yu JQ (2007) Physiological basis of different allelopathic reactions of cucumber and fig leaf gourd plants to cinnamic acid. Journal of Experimental Botany 58:3765-3773.

Divya MP, Ayyaswamy M, Bhavanisankar K (2004) Allelopathic influence of Acacia holosericea on annual crops. Indian Journal of Agroforestry 6: 47-51.

Duke SO, Dayan FE, Romagni JG, Rimando AM (2000) Natural products as sources of herbicide, current status and future trends. Weed Research 40: 99-111.

Gunarathne RMUK, Perera GAD (2016) Does the invasion of Prosopis juliflora cause the die-back of the native Manilkara hexandra in seasonally dry tropical forests of Sri Lanka? Tropical Ecology 57: 475-488.

Gupta B, Thakur NS, Das B (2007) Allelopathic effect of leaf leachates of Pinus roxburghii Sargent on seeds of some grasses. Indian Forester 133: 997-1000.

Hongying HU, Hong Y (2008) Algal-bloom control by allelopathy of aquatic macrophytes-A review. Frontiers of Environmental Science \& Engineering 2: 421-438.

Hossain MKM, Dhali AH, Hossain MS (2002) Effects of forest soil and leaf litter on germination and initial growth of Leucaena leucocephala. Allelopathy Journal 10: 13-20.

Javed K (2011) Impact of allelopathy of sunflower (Helianthus annuиs L) roots extract on physiology of wheat (Triticum aestivum L). African Journal of Biotechnology 10: 14465-14477.

Jones CD, Woods KE, Setzer WN (2012) A chemical ecological investigation of the allelopathic potential of Lamium amplexicaule and Lamium purpureum. Open Journal of Ecology 2: 167-177.

Kato-Naguchi H (2008) Allelochemicals released from rice plants. Japanese Journal of Crop Science 2: 18-25 
Kim YS, Kil B (2001) Allelopathic effects of some volatile substances from the tomato plant. Journal of Crop Production 4: 313-321.

Koder KD (2011) Black walnut allelopathy: Tree chemical warfare. Allelopathy Series 10-11: 1-13.

Lawan SA, Suleiman M, Yahaya SU (2011) Inhibition of germination and growth behavior of some cowpea varieties using neem (Azadiracta indica) leaf water Extracts. Bayero Journal of Pure and Applied Sciences 4:169-172.

Li Y, Hu T, Duan X, Zeng F, Chen H, Wu X (2013) Effects of decomposing leaf litter of Eucalyptus grandis on the growth and photosynthetic characteristics of Lolium perenne. Journal of Agricultural Science 5:123-131.

Lungu L, Popa CV, Morris J, Savoiu M (2011) Evaluation of phytotoxic activity of Melia azedarach L extracts on Lactuca sativa (L.). Romanian Biotechnological Letters 16: 6089- 6095.

Mulatu W, Gezahegn B, Befekadu B (2011) Phytotoxic effects of multi-purpose tree species on germination and growth of Parthenium hysterophorus (L.). International Journal of Agricultural Research 6: 149-162.

Murugesan S, Senthilkumar N, Rajeshkannan C, Vijayalakshmi KB (2013) Phytochemical characterizeation of Melia dubia for their biological properties. Der Chemica Sinica 4: 36-40.

Narwal SS, Pavlovic P, John J (2011) Forestry and AgroforestryResearch Methods in Plant Science, Vol 2. Studium Press Houstan Taxas USA, Pp. 249.

Nikneshan P, Hassan K, Morteza M, Nayereh-al-sadat H (2011) Allelopathic potential of sunflower on weed management in safflower and wheat. Asian Journal of Crop Science 5:1434-1440.

Nuthan D, Reddy KMC, Kumar SP, Vajranabhaiah SN, Yogeesha TD (2009) Cultivation of Melia dubia farmlands of Kanakapura taluka Ramanagara district of Karnataka-A success story. Pbli. No 224, National Afforestation and Eco-development Board (NAEB) Ministry of Environment and Forests Goveronment of India University of Agricultural Sciences, GKVK Campus Banglore India, RC, NAEB.

Parthiban KT, Bharathi AK, Seenivasan R, Kamala K, Rao MG (2009) Integrating Melia dubia in agroforestry farms as an alternate pulpwood species. APA News 34: 3-4.

Peneva A (2007) Allelopathic effect of seed extracts and powder of coffee (Coffea arabica L.) on common cocklebur (Xanthium strumarium L.). Bulgarian Journal of Agricultural Science 13: 205-211.
Perez-Corona ME, de las Heras P, Vazquez de Aldana BR (2013) Allelopathic potential of invasive Ulmus pumila on understory plant species. Allelopathy Journal 32: 101-112.

Phuwiwat W, Wichittrakarn W, Laosinwattana C, Teerarak M (2012) Inhibitory effects of Melia azedarach leaf extracts on seed germination and seedling growth of two weed species. Pakistan journal of weed science research 18: 485-492.

Prasad B, Lavania SK, Sah VK (2011) Allelopathic effects of walnut leaf extracts on seed germination and seedling growth of wheat (Triticum aestivum L.). Indian Journal of Agroforestry 13: 87-90.

Rezaeinodehi A, Khangholi S, Aminidehaghi M, Kazemi H (2006) Allelopathic potential of tea (Camellia sinensis (L) Kuntze) on germination and growth of Amaranthus retroflexus $\mathrm{L}$ and Setaria glauca (L) P Beauv. Journal of Plant Diseases and Protection 20: 447-454.

Ruan X, Li ZH, Wang Q, Pan C, Jiang D, Wang GG (2011) Autotoxicity and allelopathy of 3, 4-dihydroxyacetophenone isolated from Picea schrenkiana needles. Molecules 16: 88748893.

Sale FA, Oyun MB (2013) Inhibitory effect of leaf extract and leaf mulch from selected tree species on physiology of millet under nursery condition. Journal of Biology, Agriculture and Healthcare 3: 80-85.

Saravanan V, Parthiban KT, Kumar P, Marimuthu P (2013) Wood characterization studies on Melia dubia Cav for pulp and paper industry at different age gradation. Research Journal of Recent Science 2:183-188.

Shapla TL, Parvin R, Amin MHA, Rayhan SM (2011) Allelopathic effects of multipurpose tree species Melia azedarach with emphasis on agricultural crops. Journal of Innovative Development Strategy 5: 70-77.

Sheron OP, Tonk DS, Kaushik LS, Hasija RC, Pannu RS (1998) Statistical Software Package for Agricultural Research Workers. In: Hooda DS, Hasija RC (Eds) Recent Advances in information theory, Statistics \& Computer Applications by Department of Mathematics Statistics, CCS HAU, Hisar, India, Pp. 139-143.

Suprapti S, Djarwanto, Hudiansyah (2004) The resistance of five wood species against several wood destroying fungi. Journal of Forest Research 22: 239-246

Suzuki M, Wakana I, Takasi D, Tatewaki M (1996) An allelopathic polyunsaturated fatty acid from red algae Phytochemistry 43: 63-65. 
Thakur MK (2014) Studies on allelopathic effects of some agroforestry tree species on soybean. International Journal of Farm Sciences 4: 107-113.

Valentina P, Ilango K, Kiruthiga B, Parimala MJ (2013) Priliminary phytochemical analysis and biological careening of extracts of leaves of Melia dubia Cav. International Journal of Research in Ayurveda and Pharmacy 4: 417-719.

Vijayan P, Raghu C, Ashok G, Dhanaraj S, Suresh B (2004) Antiviral activity of medicinal plants of nilgiris including Melia dubia. Indian Journal of Medical Research 120: 24-29.

Wu HW, Pratley J, Lemerle D, An M, Liu DL (2007)
Autotoxicity of wheat (Triticum aestivum L.) as determined by laboratory bioassays. Plant Soil 296: 85-93.

Yu JQ, Ye SF, Zhang MF, Hu WH (2003) Effects of root exudates aqueous root extracts of cucumber (Cucumis sativus $\mathrm{L}$ ) and allelochemicals on photosynthesis and antioxidant enzymes in cucumber. Biochemical Systematics and Ecology 31:129-139.

Zhang Y, Gu M, Shi K, Zhou YH, Yu JQ (2010) Effects of aqueous root extracts and hydrophonic root exudates of cucumber (Cucumis sativus L.) on nuclei DNA content and expression of cell cycle-related genes in cucumber radicals. Plant Soil 327: 455-463. 